378.782(061.2) “2016/2017” Филолошки факултет https://doi.org/10.18485/godisnjak.2019.14.9

Младен В. Станић Александар Н. Илић Филип С. Љубојевић
Прегледни рад

Примљен: 15. 09.2019.

Прихваћен: 11. 10. 2019.

\title{
РАД СЕКЦИЈЕ СЦЕНСКИХ УМЕТНОСТИ ФИЛОЛОШКОГ ФАКУЛТЕТА УНИВЕРЗИТЕТА У БЕОГРАДУ ОД ШКОЛСКЕ 2016/2017. ГОДИНЕ
}

Секција сценских уметности Филолошког факултета Универзитета у Београду покренута је у мају 2014. године од стране студената Филолошког факултета. Настала на иницијацију студенткиње Зоране Манић са Катедре за српску књижевност са јужнословенским књижевностима, у сарадњи са студентом англистике Ђорђем Димитријевићем, студентом арабистике Гораном Новковићем, као и са студенткињом албанологије Љиљаном Пајовић, уз подршку Студентског парламента Филолошког факултета. Секцију су званично основали 16. априла 2015. године чланови Студентског парламента Зорана Манић и Љиљана Пајовић, а на седници Студентског парламента 12. маја усвојен је Правилник о раду Секције.

Замисао Секције јесте у томе да представља свеобухватно тело које би удружило све катедре Филолошког факултета Универзитета у Београду, без обзира на врсту и ниво студија, као и студенте других факултета Универзитета у Београду. Секцији се могу прикључити све драмске подсекције, хорови, рецитаторске секције и сл., које већ постоје на Филолошком факултету, а Секција ће тежити сарадњи са многим факултетима у Србији и шире, као и сарадњи са различитим организацијама које промовишу културу и који деле сличне амбиције.

Секција се састоји из: Управног одбора, координационог тима, организационог тима и чланова Секције. Координациони тим, заједно са организиционим тимом Секције, у сарадњи са Управним одбором 
промовише културну баштину и ваннаставну активност студената и пружа ефикасну сарадњу са факултетима, удружењима, позориштима, иностранством, културним центрима и сл. Уз помоћ тима, заједничким доприносом створили смо једно велико удружење које се бави културом на један својствен уметнички начин, а оно ће временом ширити своје границе. Секција је једно место сусрета, дружења, културно-уметничких пројеката, сарадње, праксе и промоције младих талентованих људи. Сваки вид учествовања у неком одређеном пројекту Секције носи одређене додатне ваннаставне ЕСПБ бодове који ће ићи у додатак дипломи по завршеном студирању, у складу са Правилником о вредновању ваннаставних активности студената Филолошког факултета.

\section{Школска 2016/2017. година}

Од 2016. године председник Секције је Младен Станић, студент спрске књижевности и језика са компаратистиком. Након извесних промена које уноси у организацију Секције, заједно са Управним одбором успева да повећа број чланова, али и да реализује велики број пројеката кроз различите активности у 2017. и 2018. години.

Први у низу пројеката реализованих током школске 2016/2017. године био је „Разговор са...”, у ком су своје учешће узели: Огњен Обрадовић, драматург и добитник награде Млади Дис, за збирку песама Отищаґа, Бојан Марковић, асистент на Учитељском факултету у Београду и добитник награде Млади Дис 2013. године, за песничку књигу Риба која је прогутала свет, Михајло Пантић, писац, критичар и професор на Филолошком факултету у Београду, и Горан Коруновић, асистент на Филолошком факултету и песник. Кроз сарадњу са Студентским парламентом Филолошког факултета овај пројекат реализован је у склопу Хуманијаде, па су сви они који су присуствовали трибини 17. марта 2017. године били у прилици да новчаним прилогом помогну онима којима је то најпотребније. Модератор разговора био је Младен Станић, а разговарало се о савременој књижевности, начину на који ови аутори стварају, читалачкој публици и укусу, наградама и саставима жирија.

Кроз само неколико дана, у марту месецу, тачније 25. марта, одржано је Такмичење рецитатора Филолошког факултета, први пут. Ова иницијатива потекла је од председника Секције сценских уметности, Младена Станића, а како ћемо видети, постаће традиционална манифестација која ће и Секцији пружити додатну препознатљивост и значај. 
У сали 11 Филолошког факултета публици се представило петнаесторо такмичара који нису само интерпретирали поезију већ су својим наступом указали на значај очувања лепе речи, говора и рецитаторске вештине.

На првом такмичењу рецитатора одржаном на Филолошком факултету такмичили су се:

Невена Дробњак

Песма: Плач матере човекове

Аутор: Душан Васиљев

Стеван Јовићевић

Песма: Породилиште

Аутор: Мирослав Антић

Ана Павловић

Песма: Женски Лазар

Аутор: Силвија Плат

Лидија Савић

Песма: Пишем мами песму у пицами

Аутор: Марија Шимоковић

Зоран Берић

Песма: Можда спава

Аутор: Владислав Петковић Дис

Јелена Вујовић

Песма: Узалуд је будим

Аутор: Бранко Миљковић

Душица Шундек

Песма: По растанку

Аутор: Десанка Максимовић
Ана Јовчић

Песма: Кад заборавии недељу

Аутор: Гвендолин Брукс

Сандра Трифковић

Песма: $\mathrm{OH}$

Аутор: Бранко Миљковић

Адријана Ранковић

Песма: Прича о играчкама

Аутор: Адријана Ранковић

Игор Мишуровић

Песма: Човек пева после рата

Аутор: Душан Васиљев

Тамара Стојановић

Песма: Моћ говора

Аутор: Брана Петровић

Даница Вученовић

Песма: Суние

Аутор: Даница Вученовић

Стефан Јевтовић

Песма: Како сам у возу убио човека

Аутор: Жарко Васиљевић

У жирију такмичења били су:

- Љ Љиљана Бајић, редовна професорка Филолошког факултета Универзитета у Београду

- $\quad$ Наташа Станковић Шошо, доценткиња Филолошког факултета Универзитета у Београду

- $\quad$ Мина Ђурић, доценткиња Филолошког факултета Универзитета у Београду

- $\quad$ Марија Стокић, глумица 
- Милан Босиљчић, глумац

- Сташа Петровић, драматуршкиња

Ментори такмичара били су:

- $\quad$ Младен Станић, студент Филолошког факултета и председник Секције сценских уметности Филолошког факултета

- $\quad$ Нађа Лазаревић, студенткиња Филолошког факултета и потпредседница Секције сценских уметности Филолошког факултета

Први победник овог такмичења био је Стефан Јевтовић. Друго место су поделиле Лидија Савић и Ана Павловић, док су на трећем месту били Игор Мишуровић и Невена Дробњак.

Сарадња са институцијама, медијима и различитим организацијама један је од задатака које је Секција себи поставила још при оснивању, па су се тако учесници такмичења у рецитовању 26. априла представили и на Belgrade Art Show-y, на ком је промовисан њихов рад, као и рад Секције и Филолошког факултета.

Како се у Секцији квалитетно радило на више различитих пројеката, у 2017. години изашла је и једна премијера позоришне представе. Наиме, 21. маја, у Дому омладине изведен је комад Живети или не живети, по тексту и у режији Јелене Ракиџије, студенткиње Филолошког факултета.

Да ли бисте прихватили примамљиву понуду сумњиве господе, у још сумњивијем локалу? Да ли желите да сви ваши проблеми буду решени? Колико далеко сте спремни да идете и шта све да урадите да би све ваше жеље биле задовољене? У једној обичној кафани, у једном апсурдном свету, сусрешће се најразличитије личности које ће се наћи пред великим искушењем: преко претерано амбициозне Марије, Стефана, који баш и није сигуран шта жели, заљубљеног Вука, па до оних сталних посетилаца кафане, конобарице која баш и не обавља свој посао како би требало, особе која глуми жртву и два мистериозна човека која одлучују о судбинама јунака.

Ово је прича о избору, о моралу, о прекорачењу принципа. Ово је прича о два човека за које нико не зна тачно ко су, али који су одлучили да буду главни. Ово је прича о јунацима који се баш и не питају ко су ти људи све док су њихови проблеми решени.

Улоге у представи тумачили су студенти Филолошког факултета:

А - Милош Јовановић

Б - Драгомир Влачић

Д - Биљана Бандић 
Софија - Ивана Живковић

Марија - Дијана Малешевић

Стефан - Звездан Јовановић

Вук - Омер Заимовић

Ц - Милица Тодоровић

\section{Школска 2017/2018. година}

Низ успешно реализованих пројеката чија је видљивост била велика, а успех врло запажен, како у оквиру Универзитета у Београду, тако и међу другим организацијама, али и медијима учинила је да Секција отпочне сарадњу са организацијама попут „Изражајности”, „Буфонерије”, као и институцијама: „Битеф театар”, Установа културе „Вук Караџић”, „Театар 78 ” и „Студентски културни центар”, али и да своје активности промовише на „Радио Београду 202” и „Радио телевизији Србије”.

Тако се стигло и до учешћа у организацији „Фестивала стваралаштва младих", који се реализовао у оквиру 62. МЕЂУНАРОДНОГ БЕОГРАДСКОМ САЈМА КЊИГА. Кроз четири дана Секција је имала прилику да покаже резултате свог рада, али и да у оквиру свог програма угости колеге са других факултета и истакнуте младе ствараоце.У понедељак, 23. октобра, на фестивалу су представљени рецитатори Филолошког факултета, у оквиру акције Шта нам доноси интерпретација. Посетиоци фестивала имали су прилику да чују интерпретације: Невене Дробњак, Лидије Савић, Ане Павловић, Стефана Јевтовића, Игора Мишуровића, Адријане Ранковић и Душице Шундек. Потом, 24. октобра, изведена је представа „Живети или не живети", Јелене Ракиџије. Трећег дана фестивала, 25. октобра, реализовали смо две активности у оквиру „Фестивала стваралаштва младих”. На трибини „Књижевност и друге уметности” говорили су: Вељко Ваљаревић, сликар, Јована Васић и Сара Попадић, студенткиње завршне године основних академских студија Архитектонског факултета Универзитета у Београду, Вања Марковић и Маја Милановић, виолинисткиње, а потом су о својим књигама које су биле промовисане на Сајму, у оквиру теме „Млади аутори” говорили Огњен Обрадовић, драматург, аутор збирке песама Отицања и Огњен Аксентијавић, песник, аутор збирке песама $У_{м}$ за морем, смрт за вратом. Последњег фестивалског дана о вештини беседништва, важности очувања српског језика и културе говорили су Нађа Лазаревић, песникиња, и Стефан Јевтовић. Модератор активности Секције на „Фестивалу стваралаштва младих” био је Младен Станић, председник Секције, коме је поверена и улога уредника фестивала. 
Иако организација која је потекла са Филолошког факултета, Секција је излазила из факултетског оквира и свој рад промовисала на различите начине, а посебно је значајно што су активности које је имала увек биле усмерене на промоцију културних, али и општељудских вредности. Тако се представа „Живети или не живети” играла три пута ван факултета, како би се помогло колегама са Универзитета, Анастасији Гавриловић и Милошу Станисављевићу, који су се борили са озбиљним здравстевеним проблемима. Представа је извођена 12. децембра 2017. у „Театру 78”, 5. фебруара 2018. у Установи културе „Вук Караџић” и 19. марта 2018. у „Театру 78 ”.

Друго Такмичење рецитатора Филолошког факултета одржано је 14. априла 2018. године. На њему се представило рекордних осамнаест такмичара, што је указало на велико интересовање за рад Секције, али и њену континуирану активност. Такмичари на другом такмичењу били су:

Сандра Трифковић

Песма: Та љуббав

Аутор: Жак Превер

Невена Дробњак

Песма: Сузана сузама Богу пише

Аутор: Благоје Рогач

Лука Ћупурдија

Песма: Човек пева после рата

Аутор: Душан Васиљев

Ирина Марјановић

Песма: Сан

Аутор: Љиљана Хабјановић Ђуровић

Александра Николић

Песма: Кровови

Аутор: Милена Марковић

Драгана Ћосовић

Песма: Женски Лазар

Аутор: Силвија Плат

Александра Живковић

Песма: Твоје је само да ме нађеш

Аутор: Виолета Милићевић
Кристина Весовић

Песма: Немој ићи

Аутор: Жак Брел

Стефан Јевтовић

Песма: Лехет

Аутор: Душко Трифуновић

Јована Михаила Утвић

Песма: Стојанка мајка Кнежопољка Аутор: Скендер Куленовић

Горана Самарџић

Песма: Малена Бағскка

Аутор: Милена Марковић

Стеван Јовићевић

Песма: Песма о мени

Аутор: Волт Витман

Николина Бојовић

Песма: Корак низ улииу

Аутор: Јелена Лукић

Драгица Станковић

Песма: Загрли ме

Аутор: Жак Превер 
Бојана Граоња

Песма: Плач матере човекове

Аутор: Душан Васиљев

Андријана Видојевић

Песма: Татицза

Аутор: Силвија Плат
Анастасија Куновац

Песма: Војничко писмо

Аутор: Војислав Илић Млађи

Игор Мишуровић

Песма: Како написати песму о Теодори

Аутор: Игор Мишуровић

Жири такмичења су чинили:

- $\quad$ Зона Мркаљ, редовни професор Филолошког факултета, председница „Друштва за српски језик и књижевност Србије”

- Никола Радосављевић, асистент на Филолошком факултету у Београду

- $\quad$ Ирена Плаовић, асистент на Филолошком факултету у Београду и песникиња

- $\quad$ Огњен Обрадовић, драмски писац и песник

- Ива Кевра, глумица

- орђе Живадиновић Гргур, глумац

Ментор учесника био је Младен Станић, председник Секције сценских уметности Филолошког факултета, а сарадница ментора Нађа Лазаревић, заменик председника Секције сценских уметности Филолошког факултета.

Прво место на такмичењу поделили су Ирина Марјановић и Стефан Јевтовић. Друго место је припало Драгани Ћосовић, а треће место су поделили Лука Ћупурдија, Игор Мишуровић и Александра Живковић.

У склопу акције студената Филолошког факултета „Студенти студентима”, 27. априла 2018. године председник Секције сценских уметности одржао је предавање у „Студентском културном центру”. Тема његовог излагања била је „Чему нас (ни)је научила народна књижевност”.

Младен Станић је говорио о судбини народне песме Бановић Стра$x и ґ a$, њеним варијантама које су нам до данас познате, али и како се она читала у XX веку, од стране аутора три драме и једног филмског сценарија. Полазећи од књижевног фолклора, те стижући до аутора попут Милана Огризовића, Будимира Граховца, Борислава Михајловића Михиза, али и Александара Петровића и Милене Марковић, разматран је повод за настанак уметничких дела, одступања од познатих варијаната, каква нам нова тумачења изворног текста дају аутори драма, чему нас уче.

„Излаз, партер десно” је друга премијера коју је Секција сценских уметности имала прилику да организује. У „Дому омладине”, 21. маја, на сцени су се представили: 
у улози Косте - Душан Спремо

у улози Софије - Ивана Живковић

у улози Богдана - Никола Бојовић

у улози Петра - Милош Јовановић

у улози Дијане - Дијана Малешевић

- Коста, јеси ли то урадио?

- Више не знам. Они кажу да јесам. Можда су у праву. Нека буде Софија, нека буде шта год, само нека се заврши.

Колико је лако оптужити некога у данашњем свету? Ако су сви против вас, ако сви докази упућују да сте ви криви, хоћете ли поверовати у сопствену кривицу исто онако као и они коју су вас оптужили? Хоћете ли остати? Хоћете ли отићи? Прихватите излаз и живите слободно. Зашто да не? Шта је вама остало у овом свету који вас клевеће, притиска и у којем нема више живота? Шта ћете сада урадити? Зашто се сада колебате? Нема остајања јер вама нема више помоћи. Зато отиђите, отиђите док још имате прилику. Шта је сада? Зашто се колебате?

Покренута питања нашла су своје одговоре у тексту Јелене Ракиџије. Испицијент представе била је Милица Тодоровић, а ликовни уредник Алекса Живановић.

\section{Школска 2018/2019. година}

На челу са Нађом Лазаревић и Александром Илићем, студентима српске књижевности и језика, Секција сценских уметности је у години у којој се обележавао јубилеј од краја Првог светског рата реализовала поетско-сценско вече „Крај Великог рата”. Први светски рат изазвао је велики потрес у читавом човечанству, а донео разарања и умирања. Храброст нашег народа и истрајност у борби, албанска голгота и крфска трагедија приказани су у свим уметностима, а посебно место заузели су у књижевности. Програм посвећен Великом рату обухватио је репрезентативне ауторе српске књижевности XX века, који су били сведоци трагичног времена. Публика је имала прилику да чује најлепше стихове српске модерне и авангардне поезије. Суматра Милоша Црњанског, Човек пева после рата Душана Васиљева, Бојићева Плава гробница, Шантићева Моја отаибина, Ракићево Наслеђе само су неке од песама које су казиване. За ту прилику су драматизовани одломци романа Дан шести Растка Петровића и Дневник о Чарнојевићу Милоша Црњанског. Тачка „Хероји говоре” донела је два потресна монолога ратника мајора 
Гавриловића и Милунке Савић. Тачка под називом „Идем да живим” јесте епилог читавог програма; приказана је у виду дијалога оца и сина из Андрићеве лирске прозе Ex Ponto. Аутори пројекта били су студенти Катедре за српску књижевност са јужнословенским књижевностима, Александар Илић, Филип Љубојевић и Никола Михаиловић, а у извођењу су учествовали студенти Стеван Јовићевић, Ирина Марјановић, Марија Стефановић, Драгана Ћосовић, Урош Микић, Сандра Трифковић, Нађа Лазаревић, Филип Љубојевић и Никола Михаиловић. Уз подршку професора и студената Катедре оживели смо сећање на један важан период у националној историји. Догађај се одржао 24. децембра 2018. године у Сали хероја Филолошког факултета.

Секција је и у овој години остварила сарадњу са „Театром 78” и „Битеф театром”. Колегиница Јелена Ракиџија је написала драмски текст Пет начина како да опоравите чакре након луде ноћи, по коме је режирана представа. Премијера је била 21. јуна 2019. године у „Битеф театру”. Инсципијенти представе биле су Милица Ракиџија и Милица Тодоровић, ликовни сарадник Алекса Живановић, а у представи су играли: Милорад Живковић, Ивана Живковић, Драган Кадовић, Душан Спремо, Дијана Малешевић и Катарина Јездић.

Ова представа била је и део такмичарског програма Међународног фестивала „DOPS” у Јагодини, где је освојила бројне награде и признања.

\section{Школска 2019/2020. година}

У овој школској години за председника Секције сценских уметности изабран је Александар Илић, студент српске књижевности и језика, док су за потпредседнике бирани Филип Љубојевић и Никола Михаиловић, студенти српске књижевности и језика, односно српске књижевности и језика са компаратистиком.

На првој седници Секције сценских уметности донета је одлука да први пројекат који ће се реализовати буде такмичење у рецитовању.

Ово је трећа година да се такмичење рецитатора организује, па тако постаје традиционална манифестација. Ове године било је десет такмичара, који су својим изведбама указали на важност и лепоту рецитаторске вештине. Циљ нам је био да окупимо и у рад укључимо и млађе колеге са Катедре за српску књижевност са јужнословенским књижевностима. Радионице су одржаване два пута недељно током зимског семестра, а студенти су показали изузетно интересовање, посвећеност у раду и креативност. 
Овогодишњи такмичари били су:

Момчило Ћопић

Песма: Мала моја из Босанске Крупе

Аутор: Бранко Ћопић

Сања Цветановић

Песма: (Не)разилажење

Аутор: Анастасија Куновац

Александра Живковић

Песма: Ја сам отишла у војску

Аутор: Јелена Лукић

Кристина Дидановић

Песма: Адријен

Аутор: Жак Превер

Јована Савић

Песма: Теодора

Аутор: Сима Пандуровић
Немања Пеић

Песма: Неверна супруга

Аутор: Федерико Гарсија Лорка

Теодора Миклушев

Песма: Хасанагиниияа

Народна песма

Стеван Јовићевић

Песма: Песма о мени

Аутор: Волт Витмен

Анастасија Куновац

Песма: На кули вавилонској

Аутор: Вислава Шимборска

Лука Ћупурдија

Песма: Нико осим тебе

Аутор: Чарлс Буковски

У жирију су били:

- Наташа Станковић Шошо, доценткиња Филолошког факултета Универзитета у Београду

- $\quad$ Мина Ђурић, доценткиња Филолошког факултета Универзитета у Београду

- Ненад Крцић, асистент Филолошког факултета Универзитета у Београду

- Јована Иваниш, докторанткиња Филолошког факултета Универзитета у Београду

- Младен Станић, докторанд Филолошког факултета Универзитета у Београду

Ментори учесника били су Александар Илић, председник Секције сценских уметности Фиололошког факултета, Филип Љубојевић и Никола Михаиловић, потпредседници Секције сценских уметности Филолошког факултета.

Прво место су поделили Стеван Јовићевић и Теодора Миклушев, друго Анастасија Куновац и Кристина Дидановић, а треће Јована Савић и Лука Ћупурдија. 
До краја школске године планира се реализација следећих активности: такмичење у беседништву, разговори са писцима и драмским уметницима, посете позориштима и писање позоришне критике, пројекција филмова, сценско извођење драмских дела.

Младен В. Станић Александар Н. Илић Филип С. Љубојевић 